\title{
Ryegrass endophyte, cow health and milksolids production for the 1993/94 season
}

\author{
E.R. THOM ${ }^{1}$, D.A. CLARK', R.A. PRESTIDGE ${ }^{2}$, F.H. CLARKSON' and C.D. WAUGH ${ }^{1}$ \\ 'Dairying Research Corporation, Private Bag 3123, Hamilton \\ ${ }^{2}$ AgResearch Ruakura Agricultural Centre, Private Bag 3123, Hamilton
}

\section{Abstract}

Four 2.5 ha farmlets based on endophyte-infected $(\mathrm{H})$ and endophyte-free $(\mathrm{L})$ ryegrass were established with or without white clover $( \pm C)$ in March 1993. Fifteen cows were allocated to each farmlet before 3-week test periods in spring, summer and autumn. Milk yield and composition (fat, protein, lactose), cow rectal temperature, liveweight, condition score and incidence of ryegrass staggers were measured. Pasture sampling included assessments of yield, botanical composition, alkaloid, and endophyte content. $\mathrm{H}$ and $\mathrm{L}$ endophyte ryegrass treatments contained 94 and 26\% endophyte, respectively, in March 1994. Herbage accumulation on all treatments was similar over the season (20 May 1993 - 19 April 1994). Treatments did not affect milk production in the October test period. Interaction between endophyte and clover in the January/February period showed cows on the $\mathrm{L}+\mathrm{C}$ treatment produced more milk than all others (10.3 vs 9.0 1/cow/day). However, in the March test period a different interaction was apparent $\overline{\text { as }}$ cows on the $-\mathrm{H}+\mathrm{C}$ - treatment produced less milk than all others (4.7 vs $6.3 \mathrm{I} /$ cow/day), and all cows on $\mathrm{H}$ endophyte showed clinical ryegrass staggers. Milk production responses were not directly related to the endophyte status of the pastures in any test period. Treatment trends for green herbage consumed in March were similar to those for milk production.

Keywords: Acremonium lolii, dairy cows, grazing, lolitrem B, Lolium perenne, milk production, ryegrass staggers

\section{Introduction}

Most dairy cows are grazed on pastures dominated by perennial ryegrass (Lolium perenne L.) and white clover (Trifolium repens L.), a high proportion of the ryegrass plants containing the fungal endophyte Acremonium lolii Latch, Christensen \& Samuels. The endophyte has been associated with the production of alkaloids such as peramine which acts as a feeding deterrent for Argentine stem weevil (Rowan \& Gaynor 1986) and ergopeptines and other compounds which similarly affect black beetle (Ball \& Prestidge 1993). The ergopeptines, particularly ergovaline, are also implicated in the development of heat stress symptoms in grazing animals (Fletcher 1993), and another alkaloid, lolitrem B. also produced by the endophyte, causes ryegrass staggers (Gallagher et al. 1981). Thus, dairy pastures containing endophyte-infected ryegrass have resistance to insect attack but cows may be exposed to ryegrass staggers, possible heat stress in warm regions (e.g. Northland), and undefined subclinical effects (Fletcher et al. 1990; Prestidge 1993) owing to the presence of various dietary alkaloids.

Few trials have measured the effect of ryegrass endophyte on milksolids production by dairy cows. Unpublished Manawatu work (C.W. Holmes pers. comm.) from spring 1987 to summer 1989 showed no consistent differences in milksolids yields from cows grazing pure swards of an endophyte-infected or an endophyte-free ryegrass cultivar; no clinical staggers were seen in these trials. Even in summer 1987, 4 cows which exhibited clinical signs of ryegrass staggers over the \%-week grazing period showed surprisingly small decreases in milkfat yield. Taranaki research (McCallum \& Thomson 1994) during the 1992/93 season-showed no differences in milksolids production from cows grazing pure swards of different ryegrasses associated with contrasting levels of lolitrem B and ergovaline. However, Valentine et al. (1993) reported for South Australian conditions, where cows grazed pure swards of irrigated endophyte-infected and endophyte-free lines of a New Zealand ryegrass cultivar, that $4-14 \%$ less miik was produced from the infected than from the endophyte-free line during the 1991192 season. In contrast to the reported trials, treatments imposed in the current work covered the normal mixed sward situation where the presence of white clover in the cow's diet may dilute the effects of ryegrass endophyte. This paper presents data from 1993/94, the first milk production season covered by the trial.

\section{$M$ aterials and methods}

Site

The trial was located at the Dairying Research Corporation, No. 5 Dairy, Hamilton, New Zealand. 
Rainfall was about average $(171 \mathrm{~mm})$ in March/ April 1993, but from December 1993 until March 1994 it was $33 \%$ below average $(361 \mathrm{~mm})$, with February 1994 the driest month (33 vs $70 \mathrm{~mm}$ average). Screen maximum air temperatures during the October, January/ February and March animal test periods ranged from 15.6-20.1 ${ }^{\circ} \mathrm{C}, 22.5-26.9^{\circ} \mathrm{C}$ and $18.7-25.4^{\circ} \mathrm{C}$, respectively. During the January/February test period, 12 of the 21 test days exceeded $25^{\circ} \mathrm{C}$ compared with only 2 days during the March period.

\section{Treatments and trial design}

Ryegrass treatments were established in March 1993 by cross-drilling ( $7 \mathrm{~kg} / \mathrm{ha}$ each pass) the same line of a commercial perennial ryegrass cultivar, after spraying with glyphosate $(0.72 \mathrm{~kg}$ ai/ha). Half the trial area $(20$ paddocks, each 0.25 ha) was drilled with high ("wild type' or common - $85 \%$ infection) endophyte seed $(\mathrm{H})$ and the remainder with low $(0 \%$ infection) (L) endophyte seed. Half of the $\mathrm{H}$ and $\mathrm{L}$ paddocks were established with 'normal' levels of white clover $(+\mathrm{C})$ (Grasslands Kopu also sown at $3 \mathrm{~kg} / \mathrm{ha}$ in March 1992), while the others were sprayed in December 1992 with dicamba $(0.40 \mathrm{~kg}$ ai/ha) and MCPA $(0.75 \mathrm{~kg}$ ai/ha $)$ to remove resident white clover (-C). The 4 treatments were randomly arranged in paddock pairs within 5 blocks in a $2 \times 2$ factorial design. The 10 paddocks per treatment were considered as a farmlet for grazing purposes.

To obtain sufficient area for milk yield measurements, the cows (mostly Jerseys) were grazed twice over the 10 paddocks in the 3, 21-day test periods: October (02/10/93-21/10/93), January/February (28/01/ 94-17/02/94) and March (06/03/94-24/03/94). Fifteen cows/treatment were used in the first two periods and 10 in the third, because of poor pasture growth in February/March.

\section{Pasture measurements}

Herbage DM accumulation and composition: A $0.5 \mathrm{~m}^{2}$ exclosure cage was randomly located near the centre of each paddock on 20 May 1993, and the herbage within was cut to a $2 \mathrm{~cm}$ stubble. Regrowth was assessed on 8 occasions from 19 July 1993 to 19 April 1994 by cutting a $0.25 \mathrm{~m}^{2}$ quadrat within the cage to a $2 \mathrm{~cm}$ stubble.

Fifty readings by a calibrated rising plate meter (L'Huillier \& Thomson 1988) were made before and after each grazing to estimate herbage consumed by the cows during each test period. The pre-grazing measurements provided an estimate of herbage allowance. Similarly, 40 pasture readings per paddock by a prototype radiometer (Thom et al. 1994) were averaged to provide estimates of green herbage DM before and after grazing in the March test period. These data were used to calculate green DM consumed by the cows.

Herbage clipped from the exclosure cages from JulyDecember 1993 was dissected into perennial ryegrass, white clover, Poa spp., weeds and dead material of all species. Thereafter, samples for dissection were obtained by clipping herbage at intervals on a diagonal across each paddock.

Endophyte levels: 10 ryegrass tillers were randomly selected from $10 \mathrm{H}$ and $20 \mathrm{~L}$ paddocks in August 1993, and January and March 1994, for staining and microscopic examination for the presence of endophyte mycellium.

Lolitrem B and ergovaline levels: Lolitrem B concentration was measured monthly from July 1993 in herbage samples cut to ground level on a diagonal across each paddock, and bulked within treatments. Herbage was freeze dried and finely ground before analysis using the method of Gallagher et al. (1984). Samples were also tested for ergovaline content using the method of Barker et al. (1993).

\section{Animal measurements during test periods}

During the week before each test period the cows were grazed as one herd on high endophyte ryegrass, outside the trial area. Data collected during this period were used as a covariate to adjust comparable analyses during the 3-week test period. Allocation of cows to treatments was balanced and randomisation was based on milksolids production, liveweight, condition score, and previous experimental treatment. This procedure was repeated before each test period.

Milksolids production: milk volume and composition (fat, protein and lactose) was measured twice weekly at consecutive milkings during each test period. Milksolids are defined as fat plus protein.

Rectal temperatures: hand-held digital thermometers were used to record cow rectal temperatures before afternoon milkings, on 3 days during each week of the test period and the preceeding week.

Ryegrass staggers incidence: the incidence of clinical ryegrass staggers was recorded throughout the test periods using a standard index adapted from Keogh (1973). ( $0=$ no staggers, $5=$ animal unable to stand $)$.

Liveweight and condition score: animals were weighed and visually scored for condition at the beginning and end of each test period. 


\section{Grazing management}

The trial was rotationally grazed by dairy cows, the first grazing in mid May 1993 being about 8 weeks from drilling. Over each test period, the aim was to offer similar herbage allowances to the cows on each treatment, so herbage allowance did not confound milk production responses. Each paddock was grazed twice in rotation during each test period.

\section{Fertiliser applications}

Potassium (50 kg/ha) was applied in August 1993. Urea (40 kg N/ha) was applied bi-monthly to the -C paddocks, providing a total of $280 \mathrm{~kg}$ N/ha from April 1993 to May 1994. The $+\mathrm{C}$ paddocks received $80 \mathrm{~kg} \mathrm{~N} / \mathrm{ha}$ during establishment (April-June 1993) and a further $40 \mathrm{~kg} \mathrm{~N} / \mathrm{ha}$ in December.

\section{Statistical analysis}

Analysis of variance and covariance models provided by the statistical package 'SAS' were used to test for treatment differences. Data obtained from individual cow measurements were considered as replicates for analysis of treatment differences.

\section{Results}

\section{Herbage accumulation}

Herbage_accumulations_from_20_May 1993 to 19 April 1994 were similar for all treatments, although during summer/ autumn the L-C treatment accumulated less DM (Table 1).

\section{Botanical composition of pasture}

Ryegrass and Poa dominated total DM during winter and spring (July-December, Figure 1), there being few treatment differences. Poa contributed up to $32 \%$ of DM in July but was less than $10 \%$ by December. Ryegrass content was highest in November/December

Table 1 Seasonal and total herbage DM accumulation (t DM/ ha) from 20 May 1993 to 19 April 1994.

\begin{tabular}{|c|c|c|c|c|}
\hline Treatment & $\begin{array}{l}\text { Winter } \\
(20 \text { May } \\
-1 \text { Sept })\end{array}$ & $\begin{array}{c}\text { Spring } \\
\text { (7 Oct } \\
-15 \text { Dec) }\end{array}$ & $\begin{array}{l}\text { Sum/Aut } \\
(19 \text { Jan } \\
-19 \text { Apr) }\end{array}$ & Total \\
\hline $\mathrm{H}+\mathrm{C}$ & 3.0 & 5.3 & 3.7 & 12.0 \\
\hline $\mathrm{H}-\mathrm{C}$ & 3.4 & 5.3 & 3.0 & 12.5 \\
\hline$L+C$ & 3.2 & 3.9 & 4.0 & 11.0 \\
\hline L-C & 3.4 & 5.2 & 2.7 & 11.3 \\
\hline LSD (5\%) & 0.4 & 1.2 & 0.6 & 1.0 \\
\hline
\end{tabular}

at about $85 \%$ of DM. White clover levels were variable throughout the trial, and were close to zero in $-\mathrm{C}$ treatments during winter/spring, peaking in summer (January) at about $5 \%$ of DM, then declining. White clover levels were also low (3-7\% of DM) in the $+C$ treatments up until a January peak of $15 \%$ of DM, before returning to pre-peak levels. Dead material was a major pasture component over summer/autumn peaking in all treatments in February at about 50\% of DM (Figure 1). In April there was more dead material in $\mathrm{H}$ than in $\mathrm{L}$ treatments (36 vs $24 \%$ of $\mathrm{DM}$, approx. SED=3.3).

Figure 1 Ryegrass, Poa and dead material contents (\% of DM) of high $(\mathrm{H})$ and low (L) endophyte pastures during 1993194.

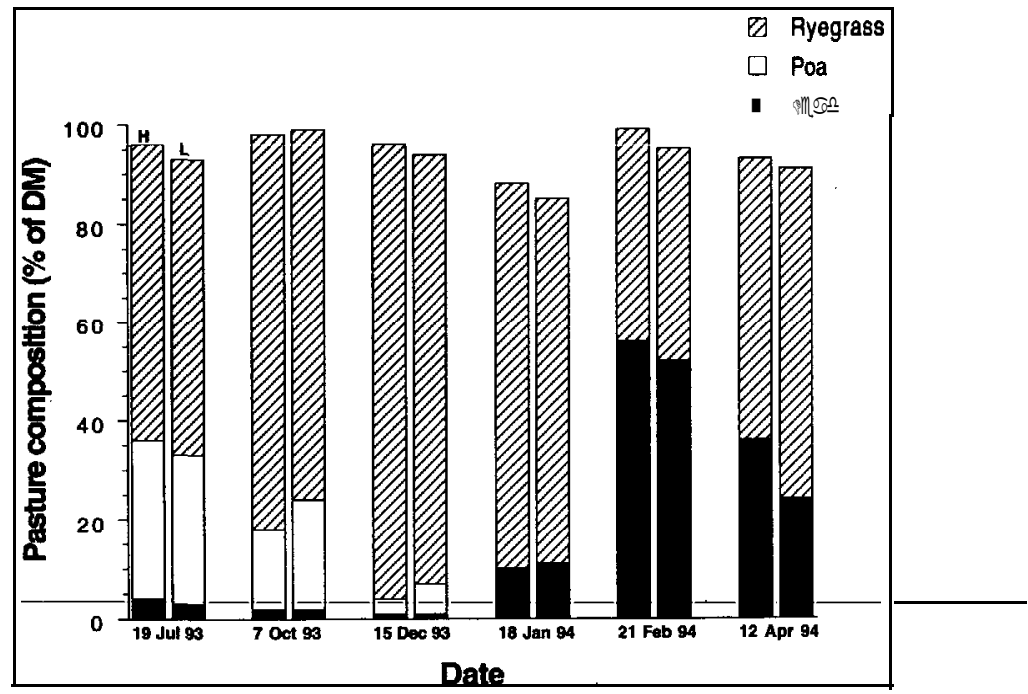

\section{Ryegrass endophyte levels}

The percentage of plants infected with endophyte increased from 81\% in August 1993 to 94\% in March 1994 for $\mathrm{H}$ areas, and similarly from $3 \%$ to $26 \%$ in L areas.

Lolitrem B and ergovaline concentrations in-ryegrass Monthly analysis showed there was $<1.5 \mu \mathrm{g} / \mathrm{g}$ DM of lolitrem B in pasture samples during winter/spring (July-December). However, in summer/autumn (January-April) levels of lolitrem B increased in all treatments, but were on average about 6-fold higher in the $\mathrm{H}$ than in the $\mathrm{L}$ treatments (Table 2). Ergovaline levels were low $(<0.5 \mu \mathrm{g} / \mathrm{g} \mathrm{DM})$ during winter/spring; in summer/autumn they increased in $\mathrm{H}$ treatments to a peak in March/April of $1.0 \mu \mathrm{g} / \mathrm{g}$ DM compared with $0.5 \mu \mathrm{g} / \mathrm{g} \mathrm{DM}$ in $\mathrm{L}$ treatments. 
Table 2 Lolitrem B concentrations $(\mu \mathrm{g} / \mathrm{g})$ in pasture DM.

\begin{tabular}{lllll}
\hline & \multicolumn{4}{c}{ Treatment } \\
Date & H+C & H.C & L+C & L.C \\
\hline 1993 & & & & \\
16 September & 0.10 & n.d. & n.d. & n.d. \\
12 October & 0.23 & 0.32 & n.d. & n.d. \\
15 November & 1.39 & 1.29 & 0.09 & 0.11 \\
13 December & 0.63 & 0.92 & 0.09 & 0.12 \\
1994 & & & & \\
11 January & & & & \\
0 February & 2.43 & 2.31 & 0.34 & 0.10 \\
8 March & 2.40 & 4.15 & 0.75 & 0.49 \\
8 April & 2.51 & 3.40 & 0.30 & 0.59 \\
\hline
\end{tabular}

n.d. = not detected above background levels $(<0.02 \mu q / \mathrm{g})$

\section{Cow pasture allowance}

Average daily pasture allowance was similar for all the cows in the October and January/February test periods. However, in March the allowance for cows on $\mathrm{L}-\mathrm{C}$ was $14 \%$ below the average for the other treatments. Radiometer estimates in March for the average green $\mathrm{DM}$ allowance show that $\mathrm{H}+\mathrm{C}$ was $20 \%$ lower than $\mathrm{H}-\mathrm{C}$ and $\mathrm{L}+\mathrm{C}$ and similar to $\mathrm{L}-\mathrm{C}$ (Table 3).

Table 3 Average daily pasture allowance (kg DM/cow/day) in the 3 test periods, and green herbage allowance ( $\mathrm{kg} \mathrm{DM} / \mathrm{cow} /$ day) in the March test period.

\begin{tabular}{lcccc}
\hline Treatment & October & January/February & \multicolumn{2}{c}{$\begin{array}{c}\text { M a r c h } \\
\text { pasture }\end{array}$} \\
& & & green \\
\hline H+C & 02 & 52 & 55 & 12.2 \\
H-C & 00 & 50 & 59 & 15.4 \\
L+C & 00 & 49 & 54 & 15.3 \\
L-C & 63 & 5347 & 5.44 & 1173.4 \\
LSD (5\%) & 9.1 & 5.34 &
\end{tabular}

\section{Cow liveweight, condition score and recta1 temper-} atures

Liveweight did not differ between treatments during the test periods and averaged 416, 405 and $393 \mathrm{~kg} /$ cow for October, January/February and March, respectively.

The average condition score of the cows did not change over each test period and was 4.9,4.9, and 4.1 for October, January/February and March, respectively. However, in October the condition scores of cows on $\mathrm{L}$ were significantly higher by 0.3 units than $\mathrm{H}$ cows, with the reverse applying in March as $\mathrm{H}$ cows exceeded $\mathrm{L}$ cows by 0.2 units.

Rectal temperatures of the cows did not differ between treatments during the test periods, averaging $38.6^{\circ} \mathrm{C}$.

\section{Incidence of ryegrass staggers}

Clinical ryegrass staggers occurred during the third week of the March test period in all cows on the $\mathrm{H}$ treatments, and was unaffected by clover treatment. The average score for the affected cows was 2.4 (exhibiting heavy tremors throughout the body), and only one cow was removed from the trial because of staggers-induced handling difficulties. No cows on the $\mathrm{L}$ treatments showed clinical symptoms of ryegrass staggers.

\section{Milk production}

No treatment differences in milk production occurred in October, but during the January/Febuary period cows on the $\mathrm{L}+\mathrm{C}$ treatment consistency produced more milk than those on the other treatments (Table 4). On average over the March period, $\mathrm{L}+\mathrm{C}$ cows produced more milk than $\mathrm{L}-\mathrm{C}$ and $\mathrm{H}+\mathrm{C}$ but not $\mathrm{H}-\mathrm{C}$. $\mathrm{H}+\mathrm{C}$ cows were also less productive than all other cows. The latter effect was strong in the first and second weeks of the period but in the third, the $\mathrm{H}+\mathrm{C}$ cows produced marginally lower $(\mathrm{P}<0.1)$ than those on $\mathrm{H}-\mathrm{C}$ and similar to those on L-C (Table 5). Trends were similar for milksolids production (Tables 4, 5).

Milk volume/cow had declined to a low level by March as the cows grazed down to low residuals (300$900 \mathrm{~kg} \mathrm{DM} / \mathrm{ha}$ - determined by quadrat cuts to about a $1.5 \mathrm{~cm}$ stubble). The cows were dried off immediately the trial finished.

Table 4 Milk volume (1/cow/day) and milksolids ( $\mathrm{kg} / \mathrm{cow} /$ day) averaged over 3-week periods in October 1993, January/February 1994 and March 1994.

\begin{tabular}{lcccccc}
\hline & \multicolumn{2}{c}{ October } & \multicolumn{2}{c}{ January/February } & \multicolumn{2}{c}{ March } \\
Treatment & Volume & Solids & Volume & Solids & Volume & Solids \\
\hline H + C & 16.0 & 1.57 & 9.2 & 0.93 & 4.7 & 0.51 \\
H - C & 16.9 & 1.60 & 9.2 & 0.90 & 6.3 & 0.66 \\
L + C & 16.9 & 1.50 & 10.3 & 1.02 & 6.0 & 0.71 \\
L - C & 15.0 & 1.40 & 0.7 & 0.07 & 5.9 & 0.62 \\
LSD (5\%) & 0.06 & 0.11 & 0.60 & 0.06 & 0.69 & 0.06 \\
\hline
\end{tabular}

Table 5 Milk volume (1/cow/day) and milksolids (kg/cow/day) production during the third week of the March test period, and average radiometer estimates of green DM consumed $(\mathrm{kg} / \mathrm{cow} / \mathrm{day})$ during the same period.

\begin{tabular}{lccc}
\hline Treatment & Milk volume & Milksolids & $\begin{array}{c}\text { Green DM } \\
\text { consumed }\end{array}$ \\
\hline H + C & 3.3 & 0.39 & 4.6 \\
H - C & 4.5 & 0.51 & 6.2 \\
L + C & 5.5 & 0.59 & 6.2 \\
L - C & 4.1 & 0.47 & 5.3 \\
LSD (5\%) & 1.3 & 0.13 & 1.3 \\
\hline
\end{tabular}




\section{Discussion}

There were inconsistent effects of treatments on milk production in the first year of this trial.

There were no effects of endophyte on milk production in the spring test period (Table 4), when lolitrem B levels in the herbage in $\mathrm{H}$ treatments averaged $0.27 \mu \mathrm{g} / \mathrm{g}$ DM (Table 2). This contrasts with Australian work (Valentine et al. 1993) where a 4\% decline in spring milk production was reported for cows grazing herbage containing average lolitrem B levels of $0.23 \mu \mathrm{g} / \mathrm{g}$ DM. McCallum \& Thomson (1994) reported no adverse effects on milk production with average spring levels of lolitrem B of $0.66 \mu \mathrm{g} / \mathrm{g} \mathrm{DM}$.

The cows on the $\mathrm{L}+\mathrm{C}$ treatment produced more milk during the January/February test period than on all other treatments (Table 4). This effect is difficult to explain since for $+\mathrm{C}$ treatments the cows on low endophyte produced $12 \%$ more milk than those on the high, while for $-\mathrm{C}$ treatments the high endophyte cow production was superior by $6 \%$. Pasture allowances were similar (Table 3) as were clover contents for $+\mathrm{C}$ treatments (approx. 15\% in January declining to 3\% of DM by mid-February).

Pasture DM was dominated by ryegrass and dead material during February/March (Figure 1), as low rainfall and grazings during the previous test period reduced the clover content to low levels in all treatments. Despite the virtual disappearance of clover before the March test period, the same trend of $\mathrm{L}+\mathrm{C}$ cows producing the most milk was evident (Table 4),

\section{although- $\mathrm{H}=\mathrm{C}-$ cows also-produced-a-similar-volume- $\mathrm{A}-$} strong treatment interaction $(P<0.001)$ was caused by cows on the $\mathrm{H}+\mathrm{C}$ treatment having inferior milk production to all other cows. This meant cows on $\mathrm{H}-\mathrm{C}$ produced $34 \%$ more milk than $\mathrm{H}+\mathrm{C}$, and those on $\mathrm{L}-\mathrm{C}$ produced $15 \%$ less than on $\mathrm{L}+\mathrm{C}$. The same interaction was evident for the third week of the March test period (Table 5) when clinical symptoms of ryegrass staggers occurred in all cows on $\mathrm{H}$ treatments. However, milk production differences between cows on $\mathrm{L}+\mathrm{C}$ and $\mathrm{L}-\mathrm{C}$ were also large $(+34 \%)$ in favour of the former. Lower summer/autumn herbage accumulation also occurred on the L-C treatment (Table 1) leading to a lower pasture allowance (Table 3). This suggests that neither lolitrem B nor the development of ryegrass staggers was the most important determinant of the results. Stress caused by intake of ergovaline was unlikely to have affected milk production since cow rectal temperatures were not elevated (Fletcher 1993) in any test period, and at least for March, ambient temperatures rarely exceeded $25^{\circ} \mathrm{C}$.

A possible explanation of the variable milk production responses could be related to the proportion of green DM consumed by the cows. The trends expressed in the analysis of green DM (Table 5) are very similar to the average milk production trends expressed for the March test period (Table 4). Pasture digestibility has been shown to be closely related to the proportion of green DM, the digestibility of which remains high throughout the year relative to dead or non-green tissues (Rattray 1978; Holmes 1987), and that intake of green DM has a strong influence on milk production (Holmes 1987). Pasture analysis (Figure 1) also shows more dead matter in $H$ than in $L$ endophyte paddocks, before and after the third test period when there was less residual DM, particularly on the L-C paddocks, and consequently less dead matter (19\% of DM) than on the other treatments $(28-39 \%$ of DM).

We believe it is necessary to investigate possible endophyte effects on milk production when ryegrass is grown with its usual companion legume, white clover. Experiments reported to date have attempted to measure endophyte effects using pure ryegrass swards, and so no measure of possible dilution effects on alkaloid concentrations from the presence of clover can be determined. Our results demonstrate that complexities arise along with the inclusion of white clover treatments which thus far have made interpretation of data more difficult, but which may clarify as the trial proceeds.

\section{Conclusions}

-The-first-season's-milk-production-responses-were variable and cannot be clearly related to the presence of endophyte and associated alkaloids like lolitrem B. It is possible that other yet to be determined chemicals associated with the endophyte are important in determining milk production responses. Alternatively, the current cow milk production responses may have little to do with alkaloids present in the diet and more to do with the proportions of green DM. The latter measurements will be extended in the following seasons.

\section{ACKNOWLEDGEMENTS}

We thank Geraldine Bourke and Sergio Marshall for technical assistance; Pat Laboyrie for assistance with grazing management; Dave Wildermoth for operating the radiometer; Rhonda Sutherland for the statistical analysis; New Zealand Agriseeds Limited for providing the ryegrass seed; Jan Sprosen (AgResearch, Ruakura) for the lolitrem B analysis; Brian Tapper and Elizabeth Davis (AgResearch, Grasslands) for the ergovaline analysis. 


\section{REFERENCES}

Ball, O.J.-P.; Prestidge, R.A. 1993. The use of the endophyte fungus Acremonium lolii as a biological control agent of black beetle Heteronychus arator (Coleoptera; Scarabaeidae). p 283-289. In Proceedings of the 6th Australasian Conference on Grassland Invertebrate Ecology. R.A. Prestidge (Ed) AgResearch, Ruakura Agricultural Research Centre, Hamilton, New Zealand.

Barker, D.J.; Davies, D.; Lane, G.A.; Latch, G.C.M.; Nott, H.M.; Tapper, B.A. 1993. Effect of water deficit on alkaloid concentrations in perennial ryegrass endophyte associations. p 67-71. In Proceedings of the Second International Symposium on Acremonium/Grass Interactions. D.E. Hume, G.C.M. Latch, H.S. Easton (Ed) AgResearch, Grasslands Research Centre, Palmerston North, new Zealand.

Fletcher, L.R. 1993. Grazing ryegrass/endophyte associations and their effect on animal health and performance. $\mathrm{p}$ 115-120. In Proceedings of the Second International Symposium on Acremonium Grass Interactions. Plenary Papers. D.E. Hume, G.C.M. Latch, H.S. Easton (Ed) AgResearch, Grasslands Research Centre, Palmerston North, New Zealand.

Fletcher, L.R.; Hoglund, J.H.; Sutherland, B.L. 1990. The impact of Acremonium endophytes in New Zealand, past, present and future. Proceedings of the New Zealand Grassland Association 52: 222 235.

Gallagher, R.T.; White, E.P.; Mortimer, P.H. 1981. Ryegrass staggers; isolation of potent neurotoxins lolitrem A and lolitrem B from staggers producing pastures. New Zealand veterinary journal 29: 189. 190.

Gallagher, R.T.; Hawkes, A.D.; Steyn, P.S.; Vleggaar, R. 1984. Tremorgenic neurotoxins from perennial ryegrass causing ryegrass staggers disorder of livestock: structure elucidation of lolitrem B. Journal of the Chemical Society, chemical communications. p. 614-616.

Holmes, C.W. 1987. Pastures for dairy cows. Chapter 11. In Feeding Livestock on Pasture. A.M. Nicol $(\boldsymbol{E d})$. Occasional Publication No. 10, New Zealand Society of Animal Production.

Keogh, R.G. 1973. Induction and prevention of ryegrass staggers in sheep. New Zealand journal of experimental agriculture 1: 55-57.

L'Huillier, P.J.; Thomson, N.A. 1988. Estimation of herbage mass in ryegrass/white clover dairy pastures. Proceedings of the New Zealand Grassland Association 49: 117- 122.

McCallum, D.A.; Thomson, N.A. 1994. The effect of different perennial ryegrass cultivars on dairy animal performance. Proceedings of the New Zealand Society of Animal Production 54: 87-90.

Prestidge, R.A. 1993. Causes and control of perennial ryegrass staggers in New Zealand. Agriculture ecosystems and environment 44: 283-300.

Rattray, P.V. 1978. Pasture constraints to sheep production. Proceedings of the Agronomy Society of New Zealand 8: 103-108.

Rowan, D.D.; Gaynor, D.L. 1986. Isolation of feeding deterrents against Argentine stem weevil from ryegrass infected withAcremonium lolii. Journal of chemical ecology 12: 647-657.

Thorn, E.R.; Hanna, M.M.; Henderson, H.V. 1994. The Hanna radiometer - status report. Unpublished DRC Report, March 1994.

Valentine, S.C.; Bartsch, B.D.; Carroll, P.D. 1993. Production and composition of milk by dairy cattle grazing high and low endophyte cultivars of perennial ryegrass. p 138-141. In Proceedings of the Second International Symposium on Acremonium/Grass Interactions. D.E. Hume, G.C.M. Latch, H.S. Easton (Ed) AgResearch, Grasslands Research Centre, Palmerston North, New Zealand. 